\title{
C) \\ $347151.0(81+44)$ \\ Emancipação e Paridade de Direitos da Mulher Casada no Brasil e nos outros Países do Sistema Jurídico Francês.
}

\author{
Rudolf Moser \\ Professor de Direito Internacional Privado na \\ Universidade de Ciências Econômicas e Sociais \\ de S. Gallen (Suiça). Professor Substituto da \\ Faculdađe de Ciências Juridicas do Rio de \\ Janeiro.
}

\section{Brasil.}

o Código Civil Brasileiro, de 1916, tem um histórico extenso e complicado ${ }^{1}$. Êle se compõe, como o Código Civil Alemão, duma Parte Geral (sôbre as pessoas, os bens, os fatos jurídicos) e duma Parte Especial relacionando-se aos direitos da família, das coisas, das obrigações e das sucessões $^{2}$ - em ordem diversa da do "BGB" alemão. Com respeito ao seu conteúdo o Código Civil Brasileiro é, por parte, uma obra original (graças à colaboração de eminentes juristas como Teixeira de Freitas, Clovis Bevilaqua e Ruy Barbosa), por parte êle segue, como fazem tôdas as co-

1. Código Civil, Lei n. ${ }^{0} 3.071$ de 1-1-1916, em vigor desde 1-1-1917, revisado por Decreto $n .^{\circ} 3.725$ de 15-1-1919 e outros; diversos anteprojetos, elaborados entre 1855 e 1899, deliberação parlamentar desde 1900. Antes do Código Civil estavam em vigência as antigas leis portuguêsas e o direito imperial.

2. Os 1.807 artigos são, em geral, concisos. Ao lado do Código Civil existe um Código Comercial, Lei $n .^{\circ} 566$ de 25-6-1850, muitą vêzes revisado e completado. 
dificações, padrões estrangeiros ${ }^{3}$, por parte exprime-se nêle o direito canônico (assim na proibição do divórcio) ${ }^{4}$; em primeiro lugar, porém, o Direito Civil Brasileiro, junto com os dos outros países latinoamericanos, faz parte da grande família do Código Civil de Napoleão.

Aos arts. 212s., 1124s. da antiga redação dêste código (de 1804) correspondeu amplamente à regulamentação até agora da capacidade de direitos e de agir da mulher casada brasileira.

\section{Capacidade de agir.}

A Lei federal brasileira no. 4121, de 27-8-1962,5 mudou diversas disposições do Código Civil, concedendo à mulher casada a plena capacidade de agir.

a) 0 art. 6 Código Civil, na redação antiga, declarou incapazes, relativamente a certos atos, i.é., incapazes de os exercer (sòzinho): I. os menores de 16 a 21 anos, II. as mulheres casadas, pela duração da sociedade conjugal, III. os pródigos e IV os selvícolas ${ }^{6}$ ! $O$ ato concluído sem cooperação pelo marido, pai ou tutor não era nulo, mas anulável, arts. 147s. do Código Civil. A nova lei (art. $10^{\circ}$ suprimiu o

3. Assim o Código Civil Português (p. ex. no regime dos bens do casal), o Código Civil Alemão (Bürgerliches Gesetzbuch, "BGD”), o Código Civil Suíço (Zivilgesetzbuch, "ZGB") admitindo, no art. 2. regra universal dêste código, art 11: "Todo homem é capaz de direitos. "

4. Desconhecem hoje o divórcio a vínculo, no sistema do Code Civil, além do Brasil, ainda o Chile, a Argentina (de nôvo), o Paraguay bem como a Itália e Espanha, enquanto Portugal e a República Dominicana permitem o divórcio dos matrimônios não celebrados conforme as leis canônicas.

5. Diário Oficial de 3-9-1962, em vigor desde 18-10-1962.

6. Os selvícolas serão liberados da tutela instituída pela legislação sôbre a proteção para os índios, na medida que êles se adaptarem à civilizaçãa. 
item II, do art. 6, abolindo desta maneira a restrição da capacidade da mulher casada. Os antigos itens III. e IV. são agora os $\mathrm{n} .{ }^{\text {s }}$ II. e III.

De acôrdo com isto, pelo art. $1^{\circ}$ da lei de 1962 , foram revogadas, na enumeração dos atos jurídicos necessitando da aprovação do marido, as disposições não motivadas pelo regime dos bens, a saber os itens. IV. (aceitação ou repudiação de herança ou legado), V. (aceitação de tutela, curatela ou de outro múnus público), VI. (litígio), VII. (exercício de profissão) e IX. (aceitação de mandato). Continuam necessitando da outorga do marido: I. aquêles atos que também o marido não poderia praticar sem consentimento da mulher ${ }^{7}$; II. a alienação e gravação de imóveis do dominio particular da mulher; III. a alheação de direitos reais da mulher sôbre imóveis de terceiros; IV. atos contraindo obrigações que podiam causar a alheação de bens do casal $^{8}$.

$\mathrm{O}$ art. 242 Código Civil tem hoje o seguinte teor:

“A mulher não pode, sem autorização do marido (art. 251) :

I. praticar os atos que êste não poderia sem consentimento da mulher (art. 235);

II. Alienar ou gravar de ônus real, os imóveis de seu domínio particular, qualquer que seja o regime dos bens (arts. 263, ns. II, III e VIII, 269, 275 e 310);

III. Alienar os seus direitos reais sôbre imóveis de outrem;

IV. Contrair obrigações que possam importar em alheação de bens do casal."

7. Prestar fiança, fazer doação, art. 235 itens III e IV. além de outros atos mais.

8. A interceção da mulher casada ante terceiro, a favor do marido, não é regulamentada “expressis verbis", vide o art. 177 al. III do Código Civil Suíço. 
b) Com respeito ao exercício de profissão pela mulher casada, esqueceu-se de revogar também o art. $1 .^{\circ}$, item 4 , do Código de Comércio que, análogo ao antigo art. 242, item VII, do Código Civil, exige a autorização do marido, o que provocou dúvidas sôbre a questão. A "ratio legis" e as demais modificações introduzidas pela nova lei justificam, porém, a tese de que a mulher casada ganhou a plena liberdade de exercer profissão ${ }^{9}$. Indo além da nova redação do Código Civil Francês, a regulamentação brasileira deixa de conferir ao marido um direito de veto, a saber de recorrer ao juiz.

A mulher pode dispôr livremente do produto do seu trabalho profissional, salvo estipulação diversa em pacto antenupcial; na medida em que fôr necessàrio, porém, ela terá que promover a manutenção da família, arts. 246,233 , 240 Código Civil, art. 2. ${ }^{\circ}$ da Lei de 1962.

$\mathrm{O}$ art. 246 do Código Civil ficou assim redigido:

"A mulher que exercer profissão lucrativa, distinta da do marido, terá direito de praticar todos os atos inerentes ao seu exercício e à sua defesa. O produto do seu trabalho assim auferido, e os bens com êle adquiridos, constituem, salvo estipulação diversa em pacto antenupcial, bens reservados, dos quais poderá dispor livremente com observância, porém, do preceituado na parte final do art. 240 e nos ns. II e III, do art. 242.

Parágrafo único. Não responde o produto do trabalho da mulher, nem os bens a que se refere êste artigo, pelas dívidas do marido, exceto as contraídas em benefício da família."

9. Veja a excelente exposição do histórico e dos argumentos neste e nos outros assuntos em questão, da professôra RUTH BARbosa GoUlART, Situação Jurídica da Mulher Casada, publicada em Jurídica, Revista trimestral da Divisão Jurídica do Instituto do Açúcar e do Alcool, XXIX abril-junho de 1964, trabalho que importou em Instruções do Departamento Nacional de Registro do Comércio, de 8-7-1965, segundo os quais prescinde de autorização marital o registro de mulher casada como comerciante individual. 
0 art. $2^{\circ}$ da Lei 1962 dispõe:

“A mulher tendo bens ou rendimentos próprios, será obrigada, como no regime da separaçâo de bens (art. 277 do Código Civil), a contribuir para as despesas comuns, se os bens comuns forem insuficientes para atendê-las."

Finalmente, no art. 248 Código Civil, a enumeração dos atos que a mulher casada pode praticar independente de autorização ficou ampliada pela frase lapidar que ela "pode livremente. VII. Praticar quaisquer outros atos não vedados por lei." As palavras "independente de autorização" foram substituídas por "livremente", e o atual item VII. citado está no lugar dos antigos itens VII. a X. os quais se tinham referido à ação anulatória do casamento, à ação de desquite, aos alimentos e ao testamento. Dêste modo, a enumeração dos atos permitidos à mulher casada tem-se transformado na cláusula geral da sua capacidade de agir irrestrita." 10

\section{Posição na sociedade conjugal.}

A Lei brasileira de 27-8-1962 melhorou também a posição da mulher casada na sociedade conjugal, equiparando os cônjuges em grande escala. Permaneceu o princípio, expresso no art. 233, que o marido é o chefe da família, o que corresponde ao art. 213 do Code Civil Français na redação de 22-9-1942 ${ }^{11}$ e ao art. 160 do Código Civil Suiço.

10. A Lei n. ${ }^{\circ} 4.121$, pelo seu primeiro artigo, modificou também o direito dos bens do casal e o direito das sucessões, vide os novos arts. 263, 269, 273, 1.579 e 1.611 Código Civil, o art. 469 do Código de Processo Civil e Comercial, assim como o art. 3 da Lei n. ${ }^{0} 4.121$. Não é possível tratar aqui destas modificações, as quais, aliás, concernem da mesma maneira a ambos os cônjuges, respectivamente ao cônjuge sobrevivente, seja o marido, seja a mulher.

11. Semelhante já a Lei de 18-2-1938, enquanto o artigo 213 do Code Civil Français estava redigido nos seguintes têrmos: "Le mari doit protection à sa femme, la femme obéissance à son mari." 
Um suplemento diz que o marido exerce esta função com a colaboração da mulher, no interêsse comum do casal e dos filhos ${ }^{12}$.

Como chefe da sociedade conjugal, compete ao marido, inalteradamente, segundo o art. 233 Código Civil, a representação legal da família, a administração dos bens comuns (e, eventualmente, dos particulares da mulher), bem como a fixação do domicílio da família, sendo agora esta última competência limitada pelo direito da mulher de recorrer ao juiz caso a deliberação do marido prejudique a ela. $O$ antigo item IV. o qual se referiu à autorização da profissão da mulher pelo marido e da residência separada dela, ficou riscado, em conformidade com a modificação citada do art. 242 Código Civil, conservando-se, no art. 231, item JI., o dever (de ambos os cônjuges) da coabitação e, no art, 36, parágrafo único, o princípio do domícilio necessário, derivado, da mulher casada. Ficou inalterado o item V., hoje IV., do art. 233 Código Civil sôbre a obrigação do marido de promover a manutenção da família, na qual a mulher tem que participar tanto quanto fôr necessário. (Vide referência acima).

$O$ art. 233 tem o seguinte teor :

"O marido é o chefe da sociedade conjugal, função que exerce com a colaboração da mulher, no interêsse comum do casal e dos filhos (arts. 240, 247 e 251).

Compete-lhe:

I. A representação legal da familia;

II. a administração dos bens comuns e dos particulares da mulher que ao marido incumbir administrar, em virtude do regime matrimonial adotado, ou de pacto antenupcial (arts. 178, parágrafo $9 .^{\circ}$, n. $^{\circ} \mathrm{I}, \mathrm{c}, 274,298, \mathrm{n} .^{\circ} \mathrm{I}$, e 311);

12. O que também corresponde ao art. 213 al. I. Código Civil Francês, cuja segunda frase diz: "Il exerce cette fonction dans l'intérêt commun du ménage et des enfants." 0 texto brasileiro juntou: "com a colaboração da mulher". 
III. o direito de fixar o domícilio da família ressalvada a possibilidade de recorrer a mulher ao Juiz, no caso de deliberação que a prejudique;

IV. prover a manutenção da família, guardadas as disposições dos arts. 275 e 277."

Em concordância com a nova redação do art. 233, relativo aos direitos e deveres do marido, o art. 240 , relativo aos da mulher, estipulou que ela assume com o casamento os apelidos do marido e a condição de sua companheira, consorte e - em vez de: auxiliar, como até aí - agora de: "colaboradora", simples palavras, pode-se observar, mas palavras nas quais as transformações e evoluções do século se manifestam. Inspirado pelo art. 213, al. II, do Código Civil Francês, o art. 240 do brasileiro impõe à mulher o dever de velar pela direção material e moral da família. Diz o art. 240 na atual redação:

"A mulher assume, com o casamento, os apelidos do marido e a condição de sua companheira, consorte e colaboradora dos encargos da familia, cumprindo-lhe velar pela direção material e moral desta."

\section{Pátrio poder.}

Além da capacidade de agir e da condição relativa ao marido, ficou fortalecida grandemente, pela nova Lei de 1962, a posição da mulher casada e mãe acêrca do pátrio poder.

Ela é hoje, neste ponto, pràticamente equiparada ao homem conquanto a sociedade conjugal está em pé, e, no caso de desquite, ela é a parte preferida. 0 art. 380 estipulou, até aí, que o marido é o chefe da família durante o casamento e que esta função compete à mulher sòmente na falta ou no impedimento dêle.

Eis o novo teor do art. 380 : 
"Durante o casamento, compete o pátrio poder aos pais, exercendo-o o marido com a colaboração da mulher. Na falta ou impedimento de um dos progenitores, passará o outro a exercê-lo com exclusividade.

Parágrafo único. Divergindo os progenitores quanto ao exercício do pátrio poder, prevalecerá a decisão do pai, ressalvada à mãe o direito de recorrer ao Juiz, para solução da divergência."

Pelo caso de desquite consensual, amigável, o art. 325 Código Civil declarou e declara o acôrdo dos cônjuges sôbre a guarda dos filhos menores como determinante. Não estavam nem estão previstos, obrigatòriamente, exame e aprovação do acôrdo em todo caso, sob o ponto de vista do bem dos filhos, pelo juiz - como o exige, p. ex., o direito suiço (veja os arts. 156 e 158, item 5, do Código Civil Suiço); todavia, poderá o juiz brasileiro, havendo motivos graves, em qualquer caso, ainda no desquite amigável, regular, a bem dos filhos, por maneira diferente da estabelecida, a situação dêles para com os pais, art. 327 (inalterado).

No caso de desquite litigioso, judicial, o bem dos filhos será melhor observado graças à nova lei da seguinte maneira: Continuam os filhos sendo postos sob a guarda do cônjuge inocente, conforme o princípio básico expresso no art. 326; porém, se ambos os cônjuges forem julgados culpados, não vale mais a antiga regra rígida segundo a qual a mãe teve direito às filhas de qualquer menor idade e dos filhos até seis anos, o pai aos filhos menores, maiores de seis anos ${ }^{13}$. Agora, todos os filhos e filhas menores ficarão em poder da mãe, salvo se o juiz temer de tal solução prejuízo moral para êles ou elas.

Junta-se, sempre pelo caso de desquite judicial, a possibilidade (introduzida já por Decreto n. ${ }^{\circ} 9701$ de 3-9-1946) de confiar os filhos, em vez de à mãe ou ao pai, a uma pessoa idônea da família de um ou outro cônjuge. Esse texto ficou

13. Este esquema ficou moderado, já até aí, pelo citado art. 327 . A maioridade começa com 21 anos, vide o art. 9 Código Civil. 
inserido ao art. 326 Código Civil pela Lei de 1962, com a modificação de que a escolha não precisa mais cair, obrigatòriamente, em um parente do cônjuge inocente, mas pode também cair em um parente do cônjuge declarado parcial ou integralmente culpado pelo desquite.

0 art. 326 revisado tem êste teor:

"Sendo desquite judicial, ficarão os filhos menores com o cônjuge inocente.

Parágrafo 1. ${ }^{\circ}$ Se ambos os cônjuges forem culpados ficarão em poder da mãe os filhos menores salvo se o juiz verificar que de tal solução advir prejuízo de ordem moral para êles.

Parágrafo $2 .^{\circ}$ Verificado que não devem os filhos permanecer em poder da mãe nem do pai, deferirá o juiz a sua guarda à pessoa notòriamente idônea da família de qualquer dos cônjuges ainda que não mantenha relações sociais com o outro, a quem, entretanto, será assegurado o direito de visita."

A mulher que contrai novo casamento - seja porque o matrimônio anterior ficou anulado, seja porque foi dissolvido pela morte do marido - perdeu, até à nova lei, o pátrio poder em relação aos filhos do leito anterior, recuperando-o no caso de se enviuvar, vide o art. 393 na redação antiga. $O$ nôvo texto dêste artigo deixa a ela o pátrio poder, acrescendo, porém, que ao (nôvo) marido, i.é. ao padrasto, não incumbe qualquer colaboração no exercício dêste poder, com as seguintes palavras :

“A mãe que contrai novas núpcias não perde, quanto aos filhos de leito anterior, os direitos ao pátrio poder, exercendo-os sem qualquer interferência do marido."

Disposição análoga pelo caso de novas núpcias do marido tendo filhos de leito anterior não há. O pai ficou com o pátrio poder já até aí, e a nova lei parece julgar desnecessário (ou, até inoportuno?) afastar a madrasta da criação dos filhos enteados - a não ser que a nova lei simplesmente não tenha dado consideração a êste caso. . 


\section{Os outros Países.}

A reforma brasileira justifica examinar, em resumo, quais as legislações cunhadas ou grandemente influenciadas pelo Código de Napoleão que conservaram o antigo principio da incapacidade ou quase-incapacidade da mulher casada e da preponderância do marido, e, do outro lado, quais as legislações que abandonaram êste princípio, emancipando a mulher casada e equiparando-a ao marido quanto aos direitos de ambos os cônjuges ${ }^{14}$.

\section{Incapacidade ou capacidade restrita.}

O sistema do antigo Code Civil continua em vigor, a grosso modo, nos seguintes países:

\section{a) Europa}

No Luxemburgo (que pertenceu à França em 1804) os referidos artigos do Code Civil Français valem ainda inalterados.

o Código Civil de Portugal, de 1867, deixou e deixa sempre de tratar da (in) capacidade da mulher casada, assim na sua primeira parte concernente a "capacidade civil", como no direito das obrigações. A Lei do casamento como contrato civil, de 25-12-1910, estipulou, no art. 39: "A sociedade conjugal baseia-se na liberdade e na igualdade. ." e revogou, pelo art. 72, o art. 1185 do Código Civil o qual, como o art. 213 do Código Civil Francês na sua antiga redação, tinha obrigado o marido a proteger a mulher e esta, a obedecer ao marido. Estão sempre em vigor, porém, os arts. 1116 e 1193s. Código Civil, segundo os quais a mulher não pode contrair dívidas sem autorização do marido nem

14. Arminjon/Nolde/WolfF, Traité de Droit comparé, v. I, 1950 , n.os 144 s. ps. 249 s. 
adquirir ou alienar bens caso a lei não o permitir especialmente. Esta regulamentação corresponde ao antigo art. 217 Código Civil Francês. O direito português do regime dos bens é mais severo ainda com a mulher do que o Código de Napoleão: Ao marido pertence, conforme o art. 1189, a administração de todos os bens do casal, direito do qual êle não pode ser privado nem por convenção antenupcial, vide o art. 1104.

A Espanha conservou, nos arts. 56s. Código Civil, de 1889, os princípios da legislação napoleônica, i. é. os arts. 212s., e isto por parte no antigo teor. Dêste modo, o art. 57 ordena: "El marido debe proteger a la mujer, y ésta, obedecer al marido." $O$ art. 61 estipula, como o fazem em Portugal os arts. 1116 e 1193s., a dependência dela da outorga marital; além disto, como o tinha declarado o antigo art. 1124 Código Civil Francês, o art. 1263, item 3, Código Civil Espanhol considera a mulher casada como principalmente incapaz, com as palavras: "No pueden prestar consentimiento:

$3^{\circ}$ Las mujeres casadas, en los casos expressados por la ley."

\section{b) América}

Na Província de Québec (Baixa Canada) continua em vigor o art. 174 Código Civil, de 1865, tendo copiado o antigo art. 213 francês ${ }^{15}$. Os arts 176 s. restringem a capacidade de agir, relativa à mulher casada, da maneira tradicional.

O Código Civil Argentino, de 1869/82,16 tinha declarado parcialmente incapaz, no seu art. 55 , a mulher casada, junto

15. Citado na nota 11. - o Code de Québec codificou, aliás, direito francês pré-napoleônico, em grande parte, vide HARoLDo VALADÃo, Le droit international privé des Etats américains, Recueil des Cours de l'Académie de Droit international de la Haye, v. 81, 1952, II ps. 5s., 32.

16. Êste código ficou influenciado não sòmente pelo Code Napoléon e a doutrina francesa, mas também pelo Código Chileno, de 1855, e as teorias de Teixeira DE Freitas, o primeiro civilista brasileiro, veja VALILADÃo p. 27. 
com os "menores adultos". A Lei n. ${ }^{0}$ 11357, de 14-9-1926, söbre os direitos civís da mulher, conferiu à mulher solteira a plena capacidade de agir, restringindo-a, porém, quanto à mulher casada, a certas competências e liberdades, de maneira que a capacidade da espôsa argentina não pode ser considerada como plena ${ }^{17}$.

Eis o art. 3 da citada lei de 1926:

"La mujer mayor de edad casada:

$1^{\circ}$ Conserva y ejerce la patria potestad de sus hijos de un matrimonio anterior.

$2^{\circ}$ Si necesidad de autorización marital o judicial, puede:

a) Ejercer profesión, oficio, empleo, comercio o industria honestos, administrando y disponiendo libremente del producido de esas ocupaciones; adquirir con el producto de su profesión, oficio, empleo, comercio o industria toda clase de bienes, pudiendo administrar y disponer de estos bienes libremente.

La mujer podrà hacer constar en la escritura de adquisición que el dinero proviene de alguno de esos conceptos. Esa manifestación importará una presunción "juris tantum".

b) Formar parte de asociaciones civiles o comerciales y de sociedades cooperativas.

c) Administrar y disponer a título oneroso de sus bienes propios y de los que le correspondan en caso de separación judicial de bienes de los esposos.

Se presume que el marido tiene mandato para administrar los bienes de la mujer, sin obligación de rendir cuentas por las rentas o frutos percibidos, mientras la mujer no haga una manifestación de voluntad contraria inscripta en un registro especial o en el de mandato donde no lo hubiere.

17. Êste estado das coisas está em contradição com a Convenção sôbre os direitos políticos e civis da mulher, assinada na IX ${ }^{a}$ Conferência Interamericana de Bogotá, em 1948, ratificada pela Argentina por Decreto n..$^{0.983}$, de 23-8-1857; segundo o art. $1 .^{\circ}$, os Estados americanos contratantes convencionaram conceder à mulher os mesmos direitos dos quais o homem goza. 
d) Administrar los bienes pertenecientes a sus hijos de un matrimonio anterior, sin que los frutos naturales o civiles de los mismos pertenezcan a la nueva sociedad conyugal.

e) Aceptar o repudiar el reconocimiento que de ella hicieren sus padres.

f) Aceptar herencia con benefício de inventario.

g) Estar en juicio en causas civiles o criminales que afecten su persona o sus bienes o a la persona o bienes de sus hijos menores de un matrimonio anterior.

h) Ser tutora, curadora, albacea, testigo en instrumentos públicos; y aceptar donaciones."

O Código Civil do Chile, de $1855,{ }^{18}$ conservou também a regulamentação napoleônica. $O$ art. 137 , na redação da Lei no. 5521, de 19-12-1934, (art. $1^{\circ}$ ), exige sempre a autorização pelo marido dos atos obrigatórios e reais (ou dispositórios) da mulher casada. Quanto ao pátrio poder, está previsto, pelos arts. 223 e 224 Código Civil, na redação da Lei no. 10271, de 2-4-1952, (art. $1^{\circ}$ ), que no caso de desquite a mãe cuidará das filhas menores, de qualquer idade, e dos filhos menores de $\mathbf{1 4}$ anos, sendo confiados ao pai os filhos menores, maiores de 14 anos.

São cópias dos arts. 212 a 214 do antigo Código Civil Francês também os arts. 176 a 179 Código Civil da Colômbia, de 1873/78. O art. 177 fala, hoje ainda, da "potestad marital" A Lei n. ${ }^{\circ}$ 28, de 1932, em vigor desde 1-1-1933, aboliu as restrições da mulher casada no regime dos bens declarando, no primeiro artigo, que cada cônjuge tem a livre administração e disposição dos seus bens anteriores e adquiridos durante o matrimônio, nos seguintes têrmos:

“Durante el matrimonio cada uno de los cónyuges tiene la libre administración y disposición tanto de los bienes que le pertenezcan al momento de contraerse el matrimonio o

18. Pela maior parte obra original de ANDRÈS BELLO, êste código tornou-se padrão para os códigos dos Estados da costa pacífica da América do Sul, veja Arminjon/Nolde/WolfF, n. ${ }^{\circ} 88$, p. 163, e ValLADÃo ps. 36s.. 
que hubiere aportado a él, como de los demás que por cualquier causa hubiere adquirido o adquiera. ."

0 art. 5 da Lei de 1932 - incorporado ao Código Civil, art. 181 - conferiu, ademais, à mulher a capacidade processual. $O$ art. 182 que tinha estatuído a incapacidade dela para os atos obrigatórios e dispositórios, ficou revogado, não sendo, porém, revogado - ao menos não explìcitamente o art. 1504 cuja alínea III. declara a mulher casada como parcialmente incapaz.

o Equador permaneceu com a antiga versão do Código Francês, ainda na revisão do Código Civil pela Lei no. 553, de 30-6-1950 ${ }^{19}$. Lêem-se assim os arts. 154 e 155:

Art. 154

"Los cónyuges están obligados a guardarse fe, socorrerse y ayudarse mutualmente en todas las circunstancias de la vida.

El marido debe protección a la mujer, y la mujer obediencia al marido."

Art. 155

"Potestad marital es el conjunto de derechos que las leyes conceden al marido sobre la persona y bienes de la mujer."

0 art. 159 nega à mulher casada a capacidade processual, com as usuais exceções; o art. 1503, item III, declara-a parcialmente capaz de contrair obrigações.

o Código Civil de Haiti, de 1825, foi também uma cópia do Código de Napoleão, arts. 212s. A Lei de 25-1-1945 melhorou a situação jurídica da mulher casada conferindo-lhe a livre disposição sôbre os bens adquiridos com o produto do seu trabalho.

19. A mesma contradição é de observar como em relação à Argentina: para com a Convenção de Bogotá, de 1948, sôbre os direitos políticos e civis da mulher, ratificada pelo Equador em 1949; veja ALFRED KARGER, Zeitschrift fuer auslaendisches und internationales Privatrecht, v. 28, 1964, ps. 658s, 664s.. 


\section{Emancipação e Paridade de Direitos.}

Aboliram a "Incapacidade da mulher casada as seguintes legislações no âmbito do sistema jurídico francês:

\section{a) Europa}

A própria França introduziu a plena capacidade pelas Leis de 18-2-1938 e 22-9-1942, esta última validada por Decreto de 9-10-1945. $O$ art. 215 al. I do Code Civil de 1938 teve o seguinte teor:

"La femme mariée a le plein exercice de sa capacité civile";

$O$ art. 216 al. I, na redação de 1942, exprime-se ainda mais claramente, assim:

"La femme mariẻe a la pleine capacité de droit."

0 art. 217, tendo, na redação antiga, de 1804, declarado a mulher casada incapaz de se obrigar e de dispôr, ficou revogado pela Lei de 1938 , junto com a referência à mulher casada nos arts. 1124s. dispondo sôbre as incapacidades no direito das obrigações. Igualmente, as demais disposições sôbre os efeitos pessoais do casamento foram profundamente modificadas, o que já foi dito acima ${ }^{20}$. Quanto ao regime dos bens, a Lei de 13-7-1965 modificou-o restringindo as prerrogativas do marido e dando à mulher a livre administração e disposição sôbre seus bens reservados, seja que ela exerça profissão separada, seja que não.

Na Bélgica a capacidade da mulher casada ficou pràticamente estabelecida por Lei de 1932 (com precursor de 1900), isto em primeiro lugar pela possibilidade de o marido a autorizar a celebrar atos jurídicos ${ }^{21}$. Pela Lei de 30-4-1958 a plena capacidade ficou pronunciada. Desde já, o art. 214 Código Civil Belga confirma que o matrimônio não produz alteração da capacidade civil dos cônjuges, ressalvados o

20. veja as notas 11 e 12 .

21. veja ARMinjón/NoLDE/WolfF, n. ${ }^{\circ}$ 147, ps. $255 \mathrm{~s}$. 
regime dos bens e a emancipação de menores pelo casamento. Conforme o art. 215, cada um dêles tem o direito de exercer, sem outorga pelo outro, profissão, ofício ou comércio, tendo contudo o outro o direito de recorrer ao juiz.

o Burgerlijk Wetboek (Código Civil) dos Países-Baixos, de 1838, adotou, no título VI. sôbre os direitos e deveres dos cônjuges, a regulamentação do velho Code Civil Français. Por Lei de 1907 juntou-se o "mandat domestique" criado pela jurisprudência francèsa em favor da espôsa. Outra lei, de 14-6-1956, remodelou essa construção no sentido da paridade jurídica dos cônjuges, a saber quanto à mútua assistência (art. 158), à guarda e educação dos filhos (art. 159 al: II) e ao sustento (art. 161). Permaneceu a restrição de o marido ser o chefe da sociedade conjuga! (art. 159 al. I), fixando êle o domicílio comum no caso de divergência sôbre esta questão. A mulher pode recorrer ao juiz contra a decisão do marido, art. 160.

o Codice Civile Italiano, de 1865, tinha seguido o Código de Napoleão na incapacidade da mulher casada, sendo porém eliminadas as normas decretando-a, por Lei de 1919. $O$ novo Codice Civile, de $16-3-1942$, não restringe mais a "capacità" dela, mas conservou, no art. 144, a disposição de que o marido é o "capo" da família, incumbindo a êle, como tal, a "potestà maritale"

Na Polônia e na România, as quais fazem hoje parte do mundo comunista, estavam em vigor, até além do fim da Segunda Guerra, leis formadas conforme o antigo Código francês.

Na chamada Polònia do Congresso houve um Código Civil, de 1825, que baseava no Código de Napoleão, introduzido na Polônia em 1808. As restrições quanto à capacidade da mulher casada decretadas por êste Código ficaram revogadas por Lei de 1-7-1921. Conforme ela, a mulher casada precisava de autorização marital sòmente quanto às disposições sôbre os bens administrados e usufruídos pelo marido. O atual Código da família, de 25-4-1964, declara, 
no art. 23, a paridade de direitos e deveres de ambos os cônjuges. Caso êles não se entendam cada um pode invocar decisão judicial, art. 24.

Na România, a incapacidade da mulher casada, instituída no Condul Civil, de 1865, foi abolida por Lei de 19-4-1932, e os arts. 25/26 do Código da família, de 21-12-1953, conferem os mesmos direitos e deveres ao homem e à mulher no casamento, obrigando-os a tomar as deliberações de comum acôrdo.

As leis polonesa ${ }^{22}$ e romena ${ }^{23}$ sôbre a capacidade de agir em geral, não contêm disposições especiais acêrca da mulher casada.

\section{b) América}

O direito civil do Estado federal da Louisiana baseia-se no Código Civil Francês ${ }^{24}$ tendo porém abolido as prerrogativas do marido, com exceção das restrições da mulher devidas ao regime dos bens.

O Código Civil do Méxicu ${ }^{25}$ foi substancialmente modificado no ano 1917 e promulgado em nova redação no dia 30-8-1928. Ele equipara plenamente marido e mulher quanto à capacidade de agir proibindo tôda postergação da mulher em relação à aquisição e ao exercício dos direitos civís. Dispõe o art. $2^{\circ}$ :

"La capacidad jurídica es igual para el hombre y la mujer; en consecuencia, la mujer no queda sometida, por razón de su sexo, a restricción alguna en la adquisición y el ejercicio de sus derechos civiles."

22. Lei de 18-7-1950 sôbre a Parte Geral do Código Civil, arts. 48s.

23. Decreto de 30-1-1954 sôbre as pessoas naturais e jurídicas, arts. $8 \mathrm{~s}$.

24. De modo mais preciso: no projeto do Código Civil Fráncês, de 1800, vide ARMinjón/NOLDE/WolfF, n. 99 p. 179.

25. O direito francês transmitiu-se ao Código mexicano por via do projeto do Código Civil Espanhol, estando em vigor, primàriamente, só no distrito e nos territórios federais do México. 
Segundo o art. 167, ambos os cônjuges têm a mesma autoridade e consideração; no caso de divergência de opiniões cabe ao juiz determinar. Todavia, a direção dos trabalhos da casa também no México está a cargo da mulher, vide o art. 168. $O$ art. 169 dispensa-a da outorga marital quanto à sua atividade profissional.

As normas têm o seguinte teor:

Art. 167

"El marido y la mujer tendràn en el hogar autoridad y consideraciones iguales; por lo tanto, de comum acuerdo arreglarán todo lo relativo a la educación y establecimiento de los hijos y a la administración de los bienes que a éstos pertenezcan.

En caso de que el marido y la mujer no estuvieren conformes sobre alguno de los puntos indicados, el juez de lo civil correspondiente procurará avenirlos, y si no lo lograre, resolverá, sin forma de juicio, lo que fuere más conveniente a los intereses de los hijos."

Art. 168

"Estará a cargo de la mujer la dirección y cuidado de los trabajos del hogar."

Art. 169

“La mujer podrá desempeñar un empleo, ejercer una profesión, industria, oficio o comercio, cuando ello no perjudique a la misión que le impone el artículo anterior, ni se dañe la moral de la familia o la estructura de ésta."

Art. 170

“El marido podrá oponerse a que la mujer se dedique a las actividades a que se refiere el artículo anterior, siempre que funde su oposición en las causas que el mismo señala. En todo caso el juez resolverá lo que sea procedente." Art. 171

"La mujer podrá oponerse a que el marido desempeñe algún trabajo que lesione la moral o la estructura de la familia. En todo caso el juez resolverá lo que sea procedente." 
A equiparação jurídica total de marido e mulher, típica nas legislações sob influência soviética ${ }^{26}$ já ficou realizada, normativamente, no México, há uns quarenta anos.

Os outros países da América do Sul também, como todos, inspiraram-se em escala maior ou menor, diretamente ou indiretamente, no Código Napoleônico ${ }^{27}$; êles também, modificando os seus códigos civis ou emitindo leis especiais, emanciparam a mulher casada e deram-lhe os direitos reservados até aí ao marido.

A Constituição da Bolivia, de 4-8-1961, garante, no seu art. 182, al. I, a paridade de homem e mulher diante da lei, usando as seguintes palavras:

“El matrimonio, la familia y la maternidad están bajo la protección del Estado. Se establece la igualdad de los cónyuges."

O Paraguay promulgou, em 1954, a Lei no. 236 sôbre os direitos civis da mulher, cujo art. 5 confere iguais direitos e igual capacidade aos cônjuges, com porém um pouco mais de prudência, i.é. assim:

"Dentro del matrimonio, la mujer y el hombre tienen los mismos derechos y la misma capacidad, con la limitación que deriva de la unidad de la familia y la diversidad de sus respectivas funciones en la sociedad."

No Perú, a paridade de direitos ficou estabelecida pelos arts. 158s. do Código Civil, de 30-8-1936, com a restrição de que o marido dirige a sociedade conjugal. Estão redigidos os arts. 158s. nestes têrmos:

Art. 158

"Los cónyuges se obligan mutuamente por el hecho del matrimonio a alimentar y educar a sus hijos."

Art. 159

26. Veja acima a situação na Polônia e România.

27. SchNITZER, Vergleichende Rechtslehre (Direito Comparado), Basel 1961, p. 197, ARMinJó́n//NOLDE/WoLfF, n. ${ }^{\circ}$ 91, p. 171, VaL ILADÃo p. 7. 


\section{"Los cónyuges se deben recíprocamente fidelidad y asistencia."}

Art. 160

"Es deber de ambos cónyuges hacer vida común en el domicilio conyugal. Cesa esta obligación cuando su cumplimiento pone en grave peligro la salud, el honor o los negocios de cualquiera de los cónyuges."

Art. 161

"El marido dirige la sociedad conyugal.

La mujer debe al marido ayuda y consejo para la prosperidad común y tiene el derecho $\mathrm{y}$ el deber de atender personalmente el hogar."

Art. 162

"Al marido compete fijar y mudar el domicilio de la familia, así como decidir sobre lo referente a su economia." Art. 163

"La mujer no está obligada a aceptar la decisión del marido cuando ésta constituye un abuso de su derecho." Quanto ao pátrio poder veja o art. 391 redigido assim: Art. 391

"La patria potestad se ejerce por el padre y la madre, durante el matrimonio. En caso de disentimiento prevalecerá la opinión del padre."

$\mathrm{Na}$ enumeração das pessoas de incapacidade absoluta ou relativa - arts. 9s. Código Civil - não figura a mulher casada; ela goza pois da plena capacidade de agir, estipulando o art. 8:

"Son personas capazes de ejercer los derechos civiles los que han cumplido 21 años."

Por Lei no. 10783, sôbre os direitos civís da mulher, de 18-9-1946, o Uruguay concedeu à mulher, seja ela solteira ou casada, os mesmos direitos que ao homem, substituindo essa lei os arts. 127s. Código Civil, de 1868, revisado em 1893 e 1914, os quais tinham copiado a regulamentação francêsa. $O$ art. $1^{\circ}$ daquela lei tem o seguinte teor:

"La mujer y el hombre tienen igual capacidad civil." 
No art. $2^{\circ}$, ficou autorizada a mulher casada a dispôr livremente dos seus bens próprios e dos frutos derivados, bem como do produto do seu trabalho. Quanto ao domicilio, ao sustento e ao pátrio poder, existe a plena paridade, conforme as seguintes disposições da citada lei:

Art. 2 al. I

"La mujer casada tiene la libre administración y disposición de sus bienes propios, de sus frutos, del producto de sus actividades y de los bienes que pueda adquirir, sin perjuicio de lo dispuesto en el artículo $5^{\circ}$ de la presente ley."

Art. 9

"El domicilio conyugal se fijará de común acuerdo por los esposos."

Art. 10

“Ambos conyuges contribuirán a los gastos del hogar (artículo 121 del Código civil) proporcionalmente a su situación económica."

Art. 11

"La patria potestad será ejercida en común por los cónyuges, sin perjuicio de las resoluciones judiciales que priven, suspendan o limiten su ejercicio o lo confieran a alguno de ellos o a otra persona, y de los convenios previstos por el art. 172 del Código Civil."

O juiz decidirá as divergências de opinião entre os cônjuges nessas matérias, vide os arts. 13 e 18.

A situação jurídica da mulher casada na Venezuela é parecida à no Perú: O Código Civil, na redação de 13-7-1942 não restringe mais a sua capacidade de agir. A plena paridade de direitos com o marido, porém, faz falta, por ser ela postergada relativo à determinação do domicílio, ao exercício do pátrio poder e - de modo geral - à deliberação sôbre os assuntos da vida conjugal. Segue-se isto das normas competentes do Código Civil, a saber dos arts. 137s. e 261 .

Art. 137 
“Los cónyuges están obligados a vivir juntos, guardarse fidelidad y socorrerse mutuamente.

La demencia, las enfermedades contagiosas y toda otra circunstancia que ponga en peligro la salud o la vida de uno de los cónyuges, son motivo para que el cónyuge amenazado pueda separarse de la habitación común."

Art. 138

"La mujer debe seguir a su marido donde quiera que fije su residencia. El Juez de Primera Instancia en lo Civil podrá, por justa causa plenamente comprobada, eximir a la mujer de este deber."

Art. 139

"El marido debe protección a la mujer y ambos deben contribuir reciprocamente a la satisfacción de sus necesidades, en la medida de los recursos y ganancias de cada uno. Esta obligación cesa para con el cónyuge que se ha separado del hogar comum sin justa causa."

Art. 140

"Al marido le corresponde la decisión en todos los asuntos relativos a la vida conyugal común."

Art. 261

"Los hijos, cualesquiera que sean su estado, edad y condición deben honrar y respetar a su padre y a sua madre, y si son menores están bajo la potestad de éstos.

La patria potestad corresponde al padre, pero en su ejercicio coadyuvará, durante el matrimonio, la madre, en lo que respecta al orden doméstico y a la dirección de los hijos. En caso de muerte del padre, de haber éste incurrido en suspensión o privación de la patria potestad, de encontrarse bajo tutela o curatela, de haber sido declarado ausente, de no estar presente, y cuando esté imposibilitado por cualquier otro motivo, la madre ejercerá la patria potestad."

As legislações da América Central também regulam de maneira liberal a posição juridica da mulher casada.

$\mathrm{O}$ art. 38 Código Civil da Guatemala, na redação de 13/21-5-1933, faz, no seu início, esta declaração fundamental : 
“El matrimonio se funda en la igualdad de derechos y obligaciones entre los contrayentes.

Aqui também, resulta a capacidade de agir da mulher casada do fato de que a lei desconhece de restrições relativas.

Em Cuba, a capacidade de direito da espôsa é irrestrita desde a Lei de 18-7-1917 sôbre a matéria. A plena igualdade jurídica ficou introduzida pela Lei de 20-12-1950 sôbre a paridade de direitos da mulher casada, tendo essa lei o seguinte teor:

Art. 1

"El artículo 57 del Código Civil, quedará redactado como sigue: Art. 57. Los esposos deben protegerse mutuamente y guardarse las consideraciones debidas."

Art. 2

“El primer párrafo del artículo 154, quedará redactado asi: Art. 154. El padre conjuntamente con la madre, y en su caso el que sobrevivo, tienen potestad sobre sus hijos legítimos no emancipados; y los hijos tienen la obligación de obedecerlos mientras permanezcan en su potestad, y de tributarles respeto y reverencia siempre."

Art. 3

"La esposa tendrá conjuntamente con el marido todos los derechos obligaciones de la patria potestad, necesitándose su consentimiento para todos los actos de administración y dominio e los hijos bajo su protección."

Art. 7

"Los cónyuges son los administradores de la sociedad de gananciales, salvo estipulación en contrario o renuncia."

Art. 8

"Los actos de administración pueden realizarse indistintamente por cualquiera de los esposos, pero para realizar cualquier acto de domínio en relación con los bienes de la sociedad de gananciales será necesario el consentimiento de ambos cónyuges." 
Art. 10

“La mujer casada podrá ejercer libremente el comercio, sin necesidad de la licencia marital."

A Constituição de Costa Rica, de 7-11-1949, decretou a absoluta igualdade de homem e mulher diante da lei, e a mesma coisa resulta duma Lei de 21-5-1953, pela qual o art. 73 Código Civil, de 1886, concernente aos efeitos pessoais do casamento, ficou alterado. Os arts. 20 s. e 627 s., sôbre as restrições da capacidade de agir no direito das pessoas e das obrigações, não tratam da mulher casada.

O Código Civil de El Salvador, antigamente de 1860, ficou revisado em 1902 no sentido da suspensão do poder marital. A mulher não figura entre as pessoas absoluta ou relativamente incapazes, a ver o art. 1318.

Conforme é a regulamentação da República Dominica$n a$, baseada nas leis de 18-12-1940 e 29-9-1949, as quais modificaram os arts. 212s. do Código Civil Francês promulgado lá no ano 1844 em língua espanhola.

A situação jurídica da mulher casada é igual em Honduras, segundo os arts. 167s. Código Civil, de 1906, em Nicarágua, conforme os arts. 151s. Código Civil, de 1904, e no Panamá, em virtude do art. 110 Código Civil, de 1916.

\section{Resumo.}

Este breve inquérito de direito comparado demonstra que países importantes, como a Espanha, a Argentina, o Chile, a Colômbia, ainda restringem a capacidade jurídica da mulher casada, mas que a maior parte das legislações inspiradas no Código de Napoleão da Europa e América, aboliram, no decorrer do vigésimo século e, em particular, desde a Primeira e Segunda Guerra Mundial, a postergação dela, concedendo-lhe a plena capacidade de agir e, pràticamente, a paridade de direitos com o marido. O Brasil, pela Lei de 1962, aderiu-se a esta maioria. 
Esta evolução, satisfatória que seja sob o ponto de vista do progresso e dos direitos humanos, não pode dissimular que os fatos reais muitas vêzes divergem da situação juridica. A mulher não alcançou ainda, no âmbito da cultura francêsa, i.é., também, na América do Sul, uma série de profissões - até das que lhe são consideradas perfeitamente convenientes na Europa Central e Setentrional bem como na América do Norte. A mulher casada, em especial, continua sendo, antes de tudo, nestes paises, a protetora do lar, sem posição ou profissão autônoma. A sua emancipação e equiparação ao homem e marido não significa aqui, por isto, a adaptação do direito a um estado das coisas já existente, mas, em primeiro lugar, a realização de um postulado legislativo de grupos adiantados ou modernistas. Todavia, a antecipação da ordem social aspirada, pelas legislações, contribuirá para a libertação da mulher nos referidos países de vínculos tradicionais. 